\title{
Amphidinin B, a New Polyketide Metabolite from Marine Dinoflagellate Amphidinium sp.
}

\author{
Takaaki Kubota, Tetsuya Endo, Yohei Takahashi, Masashi Tsuda, Jun'ichi Kobayashi \\ This paper is dedicated to the memory of Professor Kenneth L. Rinehart at University of Illinois.
}

Received: June 1, 2006 / Accepted: August 10, 2006

(C) Japan Antibiotics Research Association

\begin{abstract}
A new polyketide metabolite, amphidinin B (1), has been isolated from a marine dinoflagellate Amphidinium sp. and the structure and absolute stereochemistry were elucidated on the basis of spectroscopic data and chemical means.
\end{abstract}

Keywords amphidinin B, dinoflagellate, polyketide

\section{Introduction}

Marine dinoflagellates of the genus Amphidinium have been recognized as a source of novel secondary metabolites with interesting bioactivities [1 7]. In our continuing search for bioactive metabolites from Okinawan marine organisms, we have investigated extracts of laboratory cultured marine dinoflagellates Amphidinium sp., which were symbionts of the Okinawan marine acoel flatworms Amphiscolops sp., and isolated a series of cytotoxic macrolides, amphidinolides [1], as well as long chain polyhydroxyl polyketides $[3,6,7]$. Here we describe the isolation and structure elucidation of a new polyketide metabolite, amphidinin B (1), which was isolated from extracts of a strain (Y-56) of the dinoflagellate Amphidinium sp.

J. Kobayashi (Corresponding author), T. Kubota, T. Endo, Y. Takahashi, M. Tsuda: Graduate School of Pharmaceutical Sciences Hokkaido University, Sapporo 060-0812, Japan,

E-mail: jkobay@pharm.hokudai.ac.jp

\section{Materials and Methods}

General Procedures

NMR spectra were recorded on a Bruker AMX-600 spectrometer using $2.5 \mathrm{~mm}$ micro cells (Shigemi Co., Ltd.). The 7.20 and $128.0 \mathrm{ppm}$ resonances of residual $\mathrm{C}_{6} \mathrm{D}_{6}$ were used as internal references for ${ }^{1} \mathrm{H}$ and ${ }^{13} \mathrm{C}$ NMR spectra, respectively. FABMS spectra were obtained on a JEOL JMS-HX110 spectrometer using glycerol as a matrix in positive mode.

\section{Cultivation and Isolation}

The dinoflagellate Amphidinium sp. (strain number Y-56) was isolated from inside cells of a marine acoel flatworm Amphiscolops sp. collected off Zanpa, Okinawa. The dinoflagellate has been deposited in Graduate School of Pharmaceutical Sciences, Hokkaido University. The dinoflagellate was unialgally cultured at $25^{\circ} \mathrm{C}$ for 2 weeks in a seawater medium enriched with $1 \%$ ES supplement [8], which consisted of the following elements in 3 liters of distilled water: $\mathrm{NaNO}_{3}, 10.5 \mathrm{~g} ; \mathrm{Na}_{2} \mathrm{C}_{3} \mathrm{H}_{5}(\mathrm{OH})_{2} \mathrm{PO}_{4} \cdot 5.5 \mathrm{H}_{2} \mathrm{O}$ (sodium glycerophosphate), $1.5 \mathrm{~g} ; \mathrm{FeCl}_{3} \cdot 6 \mathrm{H}_{2} \mathrm{O}, 138 \mathrm{mg}$; $\mathrm{Na}_{2}$ EDTA $\cdot 2 \mathrm{H}_{2} \mathrm{O}$ (ethylenediaminetetraacetic acid, disodium salt), $900 \mathrm{mg} ; \mathrm{H}_{3} \mathrm{BO}_{4}, 150 \mathrm{mg} ; \mathrm{MnCl}_{2}, 30 \mathrm{mg} ; \mathrm{ZnCl}_{2}, 3.8 \mathrm{mg}$; $\mathrm{CoCl}_{2}, 0.75 \mathrm{mg}$; vitamin $\mathrm{B}_{12}, 0.3 \mathrm{mg}$; thiamine hydrochloride, $15 \mathrm{mg}$; D-biotin, $0.15 \mathrm{mg}$; tris(hydroxymethyl)aminomethane, $15 \mathrm{~g}$. The $\mathrm{pH}$ of the supplement was adjusted to 7.8 with $3 \mathrm{M}$ hydrochloric acid, prior to mixing with seawater which was sterilized by autoclaving. The harvested cells of the cultured dinoflagellate $(420 \mathrm{~g}$, wet weight, from 580 liters of culture) were extracted with $\mathrm{MeOH} /$ toluene $(3: 1)$. After addition of $1 \mathrm{M} \mathrm{NaCl}$, the mixture was extracted with 
toluene. The toluene-soluble fraction was evaporated under reduced pressure to give a residue $(3.67 \mathrm{~g})$, which was partially $(2.67 \mathrm{~g})$ subjected to a silica gel column $\left(\mathrm{CHCl}_{3} / \mathrm{MeOH}, 98: 2\right)$ and a Sep-Pak C18 cartridge $\left(\mathrm{MeOH} / \mathrm{H}_{2} \mathrm{O}, 8: 2\right)$ followed by C18 HPLC [LUNA C18(2), $5 \mu \mathrm{m}$, Phenomenex, $10 \mathrm{~mm} \times 250 \mathrm{~mm}$; eluent, $\mathrm{CH}_{3} \mathrm{CN} / \mathrm{H}_{2} \mathrm{O}$, $85: 15$; flow rate, $2.5 \mathrm{ml} /$ minute; UV detection at $210 \mathrm{~nm}$ ] to afford amphidinin B (1, $0.8 \mathrm{mg}, 0.0002 \%$, wet weight) together with known macrolides, amphidinolides $\mathrm{T} 1$ $(0.005 \%)$ [9], T3 (0.0004\%) [10], T4 (0.0002\%) [10], and T5 $(0.0004 \%)$ [11].

\section{Reductive Degradation of Amphidinin B (1)}

Amphidinin B (1, 0.1 mg) was dissolved in $\mathrm{MeOH}(50 \mu \mathrm{l})$ and treated with TMS-CHN $\mathrm{C}_{2}$ at room temperature for 1 hour. The reaction mixture was evaporated in vacuo to afford a crude residue. A solution of the residue in THF $(20 \mu \mathrm{l})$ was treated with $\mathrm{LiAlH}_{4}(1.0 \mathrm{mg})$ at room temperature for 1 hour. The reaction mixture was partitioned between EtOAc $(200 \mu \mathrm{l} \times 3)$ and $1 \mathrm{M}$ phosphate buffer $(100 \mu \mathrm{l})$. The organic phase was evaporated, and the residue was dissolved in $0.1 \%$ DMAP solution of $\mathrm{CH}_{2} \mathrm{Cl}_{2}(50 \mu \mathrm{l})$. $\mathrm{Et}_{3} \mathrm{~N}$ $(2 \mu \mathrm{l})$ and $(R)$-MTPACl $(1 \mu \mathrm{l})$ were added to the mixture and stirred at room temperature for 20 hours. After addition of $N, N$-dimethyl-1,3-propanediamine $(1 \mu 1)$, the solvent was evaporated in vacuo. The residue was purified by $\mathrm{C} 18$ HPLC (Wakosil-II 5C18 RS, Wako Pure Chemical Ind., Ltd., $4.6 \times 250 \mathrm{~mm}$; eluent $\mathrm{CH}_{3} \mathrm{CN} / \mathrm{H}_{2} \mathrm{O}, 90$ : 10; flow rate, $1.0 \mathrm{ml} /$ minute; $\mathrm{UV}$ detection at $230 \mathrm{~nm}$ ) to give compounds $\mathbf{2}$ and $\mathbf{3}[9]$.

\section{Results}

\section{Physico-chemical Properties}

Physico-chemical properties of amphidinin B (1) are summarized in Table 1. Amphidinin B (1) was soluble in methanol, chloroform, and benzene. The FAB-MS spectrum showed the molecular ion peaks at $m / z 455(\mathrm{M}+\mathrm{H})^{+}, 477$ $(\mathrm{M}+\mathrm{Na})^{+}$, and $493(\mathrm{M}+\mathrm{K})^{+}$.

\section{Structure Elucidation of Amphidinin B (1)}

Amphidinin B (1) had the molecular formula of $\mathrm{C}_{25} \mathrm{H}_{42} \mathrm{O}_{7}$ as revealed by HRFABMS $\left[\mathrm{m} / \mathrm{z} 477.2842(\mathrm{M}+\mathrm{Na})^{+}\right.$, $+1.4 \mathrm{mmu}$ ]. IR absorptions at 3400 3000, 2700 2500, and $1714 \mathrm{~cm}^{-1}$ indicated the presence of carboxylic acid functionality. ${ }^{1} \mathrm{H}$ and ${ }^{13} \mathrm{C}$ NMR data (Table 2) disclosed the presence of three carbonyl carbons, an exo-methylene, six $s p^{3}$ methines, three of which were oxygen-bearing, ten methylenes, and four methyl groups. Since four out of five unsaturations were accounted for, amphidinin B (1) was
Table 1 Pysico-chemical properties of amphidinin B (1)

\begin{tabular}{ll}
\hline Appearance & Colorless oil \\
{$[\alpha]_{D}^{24}$} & $-6^{\circ}\left(c 0.3, \mathrm{CHCl}_{3}\right)$ \\
FAB-MS $(\mathrm{m} / \mathrm{z})$ & $477(\mathrm{M}+\mathrm{Na})^{+}$ \\
HRFAB-MS $(\mathrm{m} / \mathrm{z})$ & \\
$\quad$ Found & 477.2842 \\
$\quad$ Calcd. for $(\mathrm{M}+\mathrm{Na})^{+}$ & 477.2828 \\
Molecular formula & $\mathrm{C}_{25} \mathrm{H}_{42} \mathrm{O}_{7}$ \\
\hline
\end{tabular}

inferred to contain one ring. Interpretation of the ${ }^{1} \mathrm{H}-{ }^{1} \mathrm{H}$ COSY and HOHAHA spectra of $\mathbf{1}$ revealed proton connectivities of the following units: (a) from $\mathrm{H}-2$ to $\mathrm{H}_{2}-3$ and $\mathrm{H}_{3}-22$, (b) from $\mathrm{H}_{2}-5$ to $\mathrm{H}_{3}-9$, and (c) from $\mathrm{H}-11$ to $\mathrm{H}_{2}$ 20 and $\mathrm{H}_{3}-24$, and $\mathrm{H}-17$ to $\mathrm{H}_{3}-25$ (Fig. 2). Connections among units $\mathbf{a} \sim \mathbf{c}$ and the remaining four carbons $(\mathrm{C}-1, \mathrm{C}-$ 4, C-10, and C-21) were assigned on the basis of ${ }^{1} \mathrm{H}^{13} \mathrm{C}$ long-range correlations observed in the $\mathrm{HMBC}$ spectrum as follows. $\mathrm{HMBC}$ correlations from $\mathrm{H}_{2}-3\left(\delta_{\mathrm{H}} 2.62\right.$ and 2.11) and $\mathrm{H}_{3}-22\left(\delta_{\mathrm{H}} 1.42\right)$ to the carbonyl at $\delta_{\mathrm{C}} 182.4(\mathrm{C}-1)$, and $\mathrm{H}-19\left(\delta_{\mathrm{H}} 4.44\right)$ to the carbonyl at $\delta_{\mathrm{C}} 177.4(\mathrm{C}-21)$ suggested that $\mathrm{C}-2$ and $\mathrm{C}-20$ were connected to carbonyl carbons. The connection between units $\mathbf{a}$ and $\mathbf{b}$ through an exo-methylene at C-4 was deduced from $\mathrm{HMBC}$ correlations from one proton $\left(\delta_{\mathrm{H}} 4.92\right)$ of $\mathrm{H}_{2}-23$ to $\mathrm{C}-4$ $(\delta$ 143.3) and C-3 $(\delta$ 40.3) and from another proton $\left(\delta_{\mathrm{H}} 4.93\right)$ of $\mathrm{H}_{2}-23$ to $\mathrm{C}-5(\delta 41.0)$ and $\mathrm{C}-4$. The HMBC correlation from $\mathrm{H}-19\left(\delta_{\mathrm{H}} 4.44\right)$ to $\mathrm{C}-16(\delta 81.1)$ revealed the presence of an ether linkage between C-16 and C-19, thereby constructing a tetrahydrofuran ring. The presence of an ester carbonyl at $\mathrm{C}-10$ was implied by correlations from $\mathrm{H}_{2}-12\left(\delta_{\mathrm{H}} 1.79\right.$ and 1.40$)$ and $\mathrm{H}_{3}-24\left(\delta_{\mathrm{H}} 1.21\right)$ to $\mathrm{C}-10$ $(\delta 176.0)$. The relatively lower-field resonance of H-6 $\left(\delta_{\mathrm{H}}\right.$ $5.27)$ indicated that $\mathrm{C}-6$ was involved in an ester linkage with $\mathrm{C}-10$. The HMBC correlation from $\mathrm{H}-6$ to $\mathrm{C}-10$ revealed the presence of an ester linkage between C-6 and $\mathrm{C}-10$. Relative stereochemistry of three methine protons (H-16, H-17, and H-19) in the tetrahydrofuran ring was elucidated to be 16,17-syn and 16,19-anti, since NOESY correlations were observed for $\mathrm{H}_{2}-15 / \mathrm{H}_{3}-25, \mathrm{H}-16 / \mathrm{H}-20 \mathrm{a}$, and $\mathrm{H}-19 / \mathrm{H}_{3}-25$ (Fig. 3). The absolute configurations at six chiral centers in $\mathbf{1}$ were elucidated as follows. ${ }^{1} \mathrm{H}$ NMR data of the bis- $(S)$-MTPA esters of C-1 C -9 and $\mathrm{C}-10 \sim \mathrm{C}-21$ segments ( $\mathbf{2}$ and $\mathbf{3}$, respectively), which were obtained by the successive treatments of 1 with TMS-CHN $2, \mathrm{LiAlH}_{4}$, and $(R)-\mathrm{MTPACl}$ (Scheme 1), were identical with those of bis-( $S$ )-MTPA esters of $\mathrm{C}-13 \sim \mathrm{C}-21$ and $\mathrm{C}-1 \sim \mathrm{C}-12$ segments obtained from amphidinolide $\mathrm{T} 1$ [9], respectively. Thus, the absolute configurations at $\mathrm{C}-2, \mathrm{C}-6, \mathrm{C}-11, \mathrm{C}-16$, $\mathrm{C}-17$, and $\mathrm{C}-19$ in 1 were assigned as $R, R, S, S, S$, and $R$, 
Table $2{ }^{1} \mathrm{H}$ and ${ }^{13} \mathrm{C}$ NMR data for amphidinin $\mathrm{B}(\mathbf{1})$ in $\mathrm{C}_{6} \mathrm{D}_{6}$

\begin{tabular}{|c|c|c|c|c|c|}
\hline Position & $\delta_{\mathrm{C}}$ & $\delta_{\mathrm{H}}(\mathrm{m}, \mathrm{Hz})$ & Position & $\delta_{\mathrm{C}}$ & $\delta_{\mathrm{H}}(\mathrm{m}, \mathrm{Hz})$ \\
\hline 1 & 182.4 & & 13 & 26.7 & $1.49(\mathrm{~m})$ \\
\hline 2 & 38.2 & $2.72(\mathrm{~m})$ & & & $1.34(\mathrm{~m})$ \\
\hline \multirow[t]{2}{*}{3} & 40.3 & $2.62(\mathrm{dd}, 14.9,7.8)$ & 14 & 27.3 & $1.44(\mathrm{~m})$ \\
\hline & & $2.11(\mathrm{~m})$ & & & 1.35 (m) \\
\hline 4 & 143.3 & & 15 & 30.2 & 1.49 (m) \\
\hline \multirow[t]{2}{*}{5} & 41.0 & $2.32(\mathrm{dd}, 14.5,8.2)$ & & & $1.23(\mathrm{~m})$ \\
\hline & & $2.14(\mathrm{~m})$ & 16 & 81.1 & $3.76(\mathrm{~m})$ \\
\hline 6 & 71.6 & $5.27(\mathrm{~m})$ & 17 & 36.1 & 1.90 (m) \\
\hline \multirow[t]{2}{*}{7} & 36.8 & $1.54(\mathrm{~m})$ & 18 & 39.7 & $1.47^{a}(\mathrm{~m})$ \\
\hline & & $1.44(\mathrm{~m})$ & 19 & 73.0 & $4.44(\mathrm{~m})$ \\
\hline \multirow[t]{2}{*}{8} & 18.9 & $1.42(\mathrm{~m})$ & 20 & 41.4 & $2.45(\mathrm{dd}, 14.9,8.2)$ \\
\hline & & $1.34(\mathrm{~m})$ & & & $2.24(\mathrm{~m})$ \\
\hline 9 & 14.1 & $0.92^{b}(t, 7.3)$ & 21 & 177.4 & \\
\hline 10 & 176.0 & & 22 & 17.0 & $1.42^{b}(d, 7.1)$ \\
\hline 11 & 40.0 & $2.50(\mathrm{~m})$ & 23 & 114.2 & 4.93 (s) \\
\hline \multirow[t]{3}{*}{12} & 34.0 & $1.79(\mathrm{~m})$ & & & 4.92 (s) \\
\hline & & $1.40(\mathrm{~m})$ & 24 & 17.3 & $1.21^{b}(d, 6.7)$ \\
\hline & & & 25 & 14.0 & $0.74^{b}(d, 7.1)$ \\
\hline
\end{tabular}

${ }^{a} 2 \mathrm{H} .{ }^{b} 3 \mathrm{H}$.

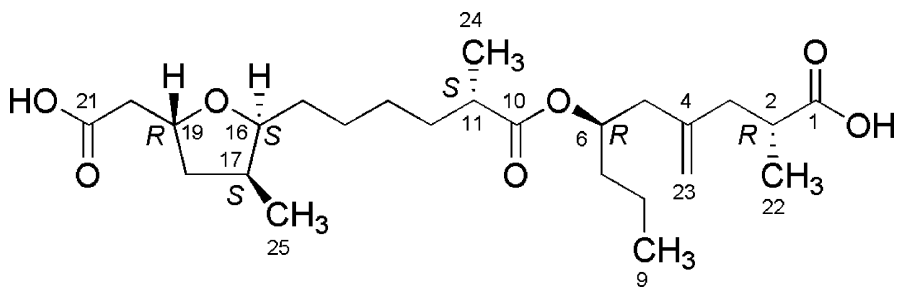

Fig. 1 Structure of amphidinin B (1).
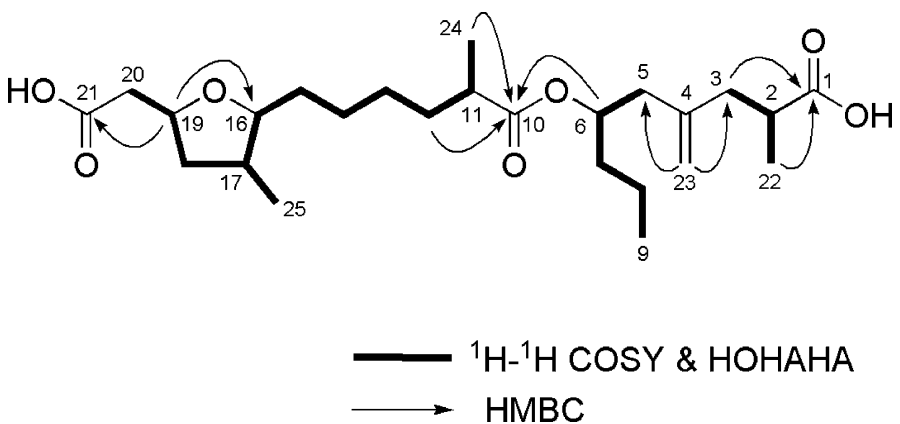

Fig. 2 Selected 2D NMR correlations for amphidinin B (1)

respectively. Thus, the structure of amphidinin B (1) was elucidated as shown in Fig. 1.

\section{Discussion}

Amphidinin B (1) is a new polyketide metabolite consisting 
two linear carbon-chain units of C-1 C-9 (C-22 and C-23) and $\mathrm{C}-10 \sim \mathrm{C}-21(\mathrm{C}-24$ and $\mathrm{C}-25)$ through an ester linkage (C-6 and C-10), possessing a tetrahydrofuran ring, one exomethylene, three branched methyls, and two carboxylic acid groups.

This is the third isolation of polyketide metabolites with a low molecular weight and no macrocyclic lactone ring from marine dinoflagellates Amphidinium sp., although amphidinin A [12] and amphidinoketides [13] have been isolated from dinoflagellates of the same genus. The backbone of 1 was the same as the carbon frameworks of 19-membered macrolides, amphidinolides T1, T3 T5. Biogenetically, amphidinin B (1) may be related to amphidinolides T1, T3 T5.

Acknowledgment The authors thank Ms. S. Oka and Ms. M. Kiuchi, Center for Instrumental Analysis, Hokkaido University, for measurements of FABMS. This work was partly supported by a Grant-in-Aid for Scientific Research from the Ministry of Education, Science, Sports and Culture of Japan.

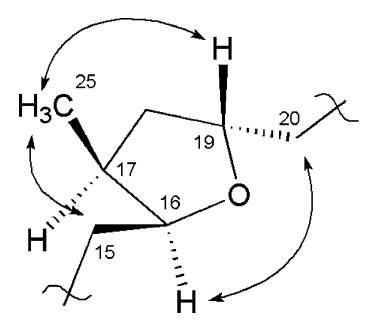

NOESY

Fig. 3 Selected NOESY correlations and relative stereochemistry for tetrahydrofuran ring of amphidinin B (1).

\section{References}

1. (a) Kobayashi J, Tsuda M. Amphidinolides, bioactive macrolides from symbiotic marine dinoflagellates. Nat Prod Rep 21: 77-93 (2004)

(b) Kubota T, Sakuma Y, Tsuda M, Kobayashi J. Amphidinolide $\mathrm{C} 2$, new macrolide from marine dinoflagellate Amphidinium species. Mar Drugs 3: 83-88 (2004)

(c) Tsuda M, Kariya Y, Iwamoto R, Fukushi E, Kawabata J, Kobayashi J. Amphidinolides B4 and B5, potent cytotoxic 26-membered macrolides from dinoflagellate Amphidinium species. Mar Drugs 3: 1-8 (2005)

2. (a) Satake M, Murata M, Yasumoto T, Fujita T, Naoki H. Amphidinol, a polyhydroxypolyene antifungal agent with an unprecedented structure, from a marine dinoflagellate, Amphidnium klebsii. J Am Chem Soc 113: 9859-9861 (1991)

(b) Paul GK, Matsumori N, Murata M, Tachibana K. Isolation and chemical structure of amphidinol 2, a potent hemolytic compound from marine dinoflagellate Amphidinium klebsii. Tetrahedron Lett 36: 6279-6282 (1995)

(c) Paul GK, Matsumori N, Konoki K, Murata M, Tachibana $\mathrm{K}$. Chemical structures of amphidinols 5 and 6 isolated from marine dinoflagellate Amphidinium klebsii and their cholesterol-dependent membrane disruption. J Mar Biotechnol 5: 124-128 (1997)

(d) Echigoya R, Rhodes L, Oshima Y, Satake M. The structures of five new antifungal and hemolytic amphidinol analogs from Amphidinium carterae collected in New Zealand. Harmful Algae 4: 383-389 (2005)

(e) Morsy M, Matsuoka S, Houdai T, Matsumori N, Adachi S, Murata M, Iwashita T, Fujita T. Isolation and structure elucidation of a new amphidinol with a truncated polyhydroxyl chain from Amphidinium klebsii. Tetrahedron 61: 8606-8610 (2005)

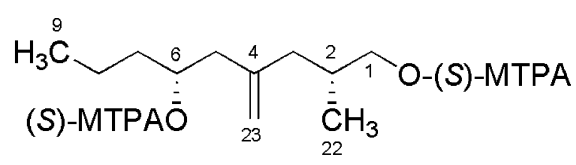

2
1) $\mathrm{TMS}_{-} \mathrm{CHN}$

1 2) $\mathrm{LiAlH}_{4}$

3) (R)-MTPACl

4) $\mathrm{C}_{18} \mathrm{HPLC}$ separation

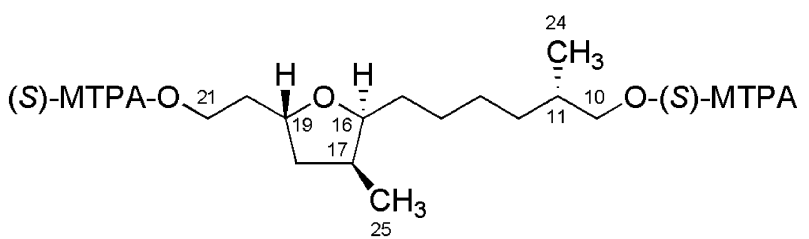

3

Scheme 1 Reductive degradation of amphidinin B (1) and preparation of the MTPA esters (2) and (3) of degradation products. 
3. (a) Doi Y, Ishibashi M, Nakamichi H, Kosaka T, Ishikawa T, Kobayashi J. Luteophanol A, a new polyhydroxyl compound from symbiotic marine dinoflagellate Amphidinium sp. J Org Chem 62: 3820-3823 (1997)

(b) Kubota T, Tsuda M, Doi Y, Takahashi A, Nakamichi H, Ishibashi M, Fukushi E, Kawabata J, Kobayashi J. Luteophanols B and C, new polyhydroxyl compounds from marine dinoflagellate Amphidinium sp. Tetrahedron 54: 14455-14464 (1998)

(c) Kubota T, Takahashi A, Tsuda M, Kobayashi J. Luteophanol D, new polyhydroxyl metabolite from marine dinoflagellate Amphidinium sp. Mar Drugs 3: 113-118 (2005)

4. (a) Huang X, Zhao D, Guo Y, Wu H, Lin L, Wang Z, Ding J, Lin Y. Lingshuiol, a novel polyhydroxyl compound with strongly cytotoxic activity from the marine dinoflagellate Amphidinium sp. Bioorg Med Chem Lett 14: 3117-3120 (2004)

(b) Huang X, Zhao D, Guo Y, Wu H, Trivellone E, Cimino G. Lingshuiols A and B, two new polyhydroxy compounds from the Chinese marine dinoflagellate Amphidinium sp. Tetrahedron Lett 45: 5501-5504 (2004)

5. Washida K, Koyama T, Yamada K, Kita M, Uemura D. Karatungiols A and B, two novel antimicrobial compounds, from the symbiotic marine Amphidinium sp. Tetrahedron Lett 47: 2521-2525 (2006)

6. (a) Kobayashi J, Kubota T, Takahashi M, Ishibashi M, Tsuda M, Naoki H. Colopsinol A, a novel polyhydroxyl metabolite from marine dinoflagellate Amphidinium sp. J Org Chem 64: 1478-1482 (1999)

(b) Kubota T, Tsuda M, Takahashi M, Ishibashi M, Naoki H, Kobayashi J. Colopsinols B and C, new long chain polyhydroxyl compounds from cultured marine dinoflagellate Amphidinium sp. J Chem Soc, Perkin Trans 1 64: 3483-3487 (1999)

(c) Kubota T, Tsuda M, Takahashi M, Ishibashi M, Oka S, Kobayashi J. Colopsinols D and E, new polyhydroxyl linear carbon chain compounds from marine dinoflagellate Amphidinium sp. Chem Pharm Bull 48: 1447-1451 (2000)

7. Kubota T, Sakuma Y, Shimbo K, Tsuda M, Nakano M, Uozumi Y, Kobayashi J. Amphezonol A, a novel polyhydroxyl metabolite from marine dinoflagellate Amphidinium sp. Tetrahedron Lett 47: 4369-4371 (2006)

8. Provasoli L. In: Culture and Collection of Algae. Watanabe A., Hattori A. (eds.). Japanese Society of Plant Physiology, Tokyo, pp. 63-75 (1968)

9. Tsuda M, Endo T, Kobayashi J. Amphidinolide T, novel 19-membered macrolide from marine dinoflagellate Amphidinium sp. J Org Chem 65: 1349-1352 (2000)

10. Kobayashi J, Kubota T, Endo T, Tsuda, M. Amphidinolides T2, T3, and T4, new 19-membered from the dinoflagellate Amphidinium sp. and Amphidinolide T1. J Org Chem 66: 134-142 (2001)

11. Kubota T, Endo T, Tsuda M, Shiro M, Kobayashi J. Amphidinolide T5, a new 19-membered macrolide from a dinoflagellate and X-ray structure of amphidinolide T1. Tetrahedron 57: 6175-6179 (2001)

12. Kobayashi J, Yamaguchi N, Ishibashi M. Amphidinin A, a novel amphidinolide-related metabolite from the cultured marine dinoflagellate Amphidinium sp. Tetrahedron Lett 35: 7049-7050 (1994)

13. Bauer I, Maranda L, Young KA, Shimizu Y. The isolation and structures of unusual 1,4-polyketides from the dinoflagellate, Amphidinium sp. Tetrahedron Lett 36: 991-994 (1995) 